Investigaciones Fenomenológicas, vol. Monográfico 7, 2018, 27-34 e-ISSN: $1885-1088$

\title{
LESTER EMBREE'S CONTRIBUTIONS TO PHENOMENOLOGY AS A PRACTICAL ENTERPRISE
}

\section{CONTRIBUCIONES DE LESTER EMBREe A LA fENOMENOLOGÍA COMO UNA TAREA PRÁCTICA}

Thomas Nenon University of Memphis tnenon@memphis.edu

Within the phenomenological tradition, there has long been a clear awareness that science and philosophy are not merely aggregations or even systematic and internally consistent sets of propositions, but also practices that are undertaken by human beings with certain aims and interests ${ }^{1}$. One recalls, for instance, Martin Heidegger's important insight articulated at the very beginning of Being and Time, that science is something human beings do-or as he puts it, a Verhalten des Daseins ${ }^{2}$. Moreover, even before Heidegger, Edmund Husserl, who in the Logical Investigations introduced science as a set of logically interrelated truths and is often presented as a modern day Descartes operating within the pure egological bubble of his own solitary reflections, was the same figure who devoted much of his final work to the question of how the modern ways of practicing science emerged, who made clear that all of this takes place against a common set of shared cultural assumptions, and who was well aware that even

\footnotetext{
${ }^{1}$ This essay is an updated and revised version of a paper "Advancing Phenomenology as a Practical Endeavor" that was published in T. Nenon / P. Blosser (eds.), Advancing Phenomenology: Essays in Honor of Lester Embree, Dordrecht: Springer 2010, pp. 257-263. That essay has been updated and translated into Spanish by Carlos Alberto Sánchez as "La promoción de la fenomenología como esfuerzo práctico", Acta Mexicana de Fenomenología 2 (2017) 203-219.

2 Martin Heidegger, Sein und Zeit (Tübingen: Niemeyer, 1956), pp. 11-13; translated by John Macquarrie and Edward Robinson as Being and Time, New York: Harper \& Row, 1962, pp. 32f.
} 
his own phenomenological work is merely part of a shared research project that he hoped would be taken up and continued by other researchers throughout subsequent generations ${ }^{3}$. So within the phenomenological tradition it has been clear from that outset that, if phenomenology is to become and stay a reality, it must become a tradition, a project that is taken up and remains alive by being enacted over and again by persons across generations. At least within the Husserlian variation, phenomenology soon also became a movement that consciously made an effort to transcend national boundaries. For instance, the number of Husserl's students from France and Eastern Europe was remarkable, and their subsequent impact on philosophical life in their native countries was significant; but also-and in spite of his controversial claims about philosophy as a "European" calling-he had several important students who came from countries outside of Europe, in particular Japanese students such as Satomi Takahashi and Kitaro Nishida (who read and were strongly influenced by Husserl but did not study under Husserl), as well as Shuzo Kuki, Tokuryu Yamanouchi, and Hasime Tanabe (who did study under Husserl himself) ${ }^{4}$, and a few North American students such as Winfried Bell, Marvin Farber, and Dorion Cairns who later played significant roles in the development of phenomenology as a significant movement in their parts of the world. Of course, phenomenology is not the only philosophical school or movement that has recognized that science can be seen as a practice, that it is a shared enterprise, and that it can transcend cultural and national boundaries; however, these themes have figured prominently in phenomenology from the outset, and it is important to note that these insights have practical as well as theoretical implications. One of those implications is that phenomenology as a movement flourishes not just through publications, but also through personal contacts and institutions. Moreover, even its publications would not be possible without the establishment of journals, book series, etc., that are open to the phenomenological mode of scholarly inquiry and reflection; and those also require practical and organizational work and talents. Again, this is not something true just about phenomenology, but of every philosophical or intellectual

\footnotetext{
${ }^{3}$ In Edmund Husserl, Die Krisis der europäischen Wissenschaft und die transzendentale Phänomenologie in: Husserliana, Band VI (Den Haag: M. Nijhoff, 1962; translated by David Carr as The Crisis of European Sciences and Transcendental Phenomenology, Evanston: Northwestern University Press, 1970.

${ }^{4} \mathrm{~A}$ very helpful overview of these and other students can be found in Hans Rainer Sepp (ed.), Edmund Husserl und die phänmenologische Bewegung: Zeugnisse in Text und Bild, Freiburg/Munich: Alber, 1988, pp. 422-442. See also the Encyclopedia of Phenomenology, ed. Lester Embree et al., Dordrecht: Kluwer, 1997.
} 
movement, but at an early stage in the development of phenomenology, an explicit awareness and thematization of this insight arose-which is not true of every philosophical approach. For over four decades, Lester Embree contributed greatly to the practical work of advancing phenomenology, first primarily through his work in North America, then over the next two decades, increasingly through his efforts on behalf of actively supporting phenomenological work in other parts of the world and in bringing together active scholars from philosophy-and, as he would be among the first to emphasize-other disciplines such as psychology, nursing, archeology, and architecture, to name just a few examples, from around the world together to learn from and support each others' work and to promote phenomenology as a global interactive practice.

Embree's organizational work in phenomenology began during the final years of his graduate work at the New School for Social Research, which was at the time clearly the leading department in the United States for phenomenology. Founded in the 1930 s as the German University in Exile, it brought together scholars trained in the phenomenological tradition who had been forced to leave their native countries and continue their work in phenomenology in their new homes in America. By the time Lester Embree arrived at the New School, these had included Alfred Schutz, Aron Gurwitsch, Werner Marx, Hans Jonas, and Kurt Riezler, as well as Husserl's outstanding American student Dorion Cairns; and Gurwitsch, Marx, Jonas, and Cairns were still there. In 1971, Lester Embree came together with several other advanced graduate students and recent graduates from the New School for Social Research to help preserve and advance the legacy of their teachers who had played a leading role in introducing phenomenology in America. They founded the Center for Advanced Research in Phenomenology, Inc. (CARP) that was to play an important role in the philosophical scene in North America in a number of ways that will be described below. Richard Zaner served as its first president; Lester Embree was named secretary. The initial task for CARP was the establishment of an Archival Repository that could help preserve the manuscripts and papers of their teachers and other scholars within the phenomenological tradition. The success of this part of CARP's mission is evidenced not just by the microfilm copies of the papers and manuscripts left by Alfred Schutz and Hannah Arendt that are still part of the collection as well as the originals of the papers of Dorion Cairns, the sociologist Helmut Wagner, Felix Kaufmann, Erwin Strauss, Herbert Spiegelberg, and photocopies of Winthrop 
Bell's papers, along with many other documents that illustrate the history of phenomenology in North America such as proceedings of early meetings of the Husserl Circle, the Heidegger Circle, and the International Workshop on Phenomenology that was held in 1974 in Berlin 5 . More importantly, these papers were not merely preserved, but Lester Embree has played a large role over the years in making sure that they were easily accessible to a larger scholarly audience in published form, for example in the editions of the Schutz-Gurwitsch correspondence, Aron Gurwitsch's Marginal Consciousness and his Phenomenology and the Theory of Science, Alfred Schutz's Collected Papers, the edition of works by Aron Gurwitsch, and the ongoing multivolume edition of the unpublished lectures and essays by Dorion Cairns. Indeed, as an editor and coeditor, Lester Embree was been involved in an extremely impressive array of papers and volumes from phenomenology over the past three and a half decades. This included over 60 edited volumes-beginning in 1972 with a Festschrift for Aron Gurwitsch, then continuing with the publication of writings by his New School teachers Schutz, Cairns, and Gurwitsch mentioned above, and then extending to collections documenting the discussion of phenomenological philosophers and, from Embree's perspective, even more importantly, of phenomenology that have taken place in conferences that he took a leading role in organizing for nearly four decades with scholars from around the world.

Embree supported the work of other phenomenologists not just through his editorial work, but through the key role he played in establishing venues for publishing work in this area. Working with other members of the Center for Advanced Research in Phenomenology, Embree played an important role establishment of the "Series in Continental Thought" with the Ohio University Press, where he also served as Chairman of the Editorial Board from 1978 through 1984, and the series "Current Continental Research" that was copublished with the University Press of America. He also served as Chairman of its editorial board from 1981 through 1997. While Lester Embree was President of CARP, CARP established the series "Contributions to Phenomenology" (CTP) with Bill McKenna as the founding editor of that series with Kluwer Academic Publishers (now Springer Verlag). This series, now with over 92 volumes, has

\footnotetext{
${ }^{5}$ An overview of the Archival Repository, currently housed in the Ned McWhorter University Libraries at the University of Memphis can be found on the CARP website at www. phenomenologycenter.org. 
since served as one of the most important series for current research in phenomenology since its inception in 1988; it includes 15 volumes in which Embree served as editor or co-editor. Embree was also one of the "early adopters" in the realm of electronic publishing that is becoming ever more important in the twenty-first century and opens up new possibilities for the global dissemination of scholarly work because of its significantly lower costs and easy accessibility anywhere in the world that students and scholars have access to the internet. In 2001, he edited-together with Steven Crowell and Samuel J. Julianan extensive collection of essays with the title The Reach of Reflection: Issues for Phenomenology's Second Century with the newly founded Electronpress at www.electronpress.com. He also played a key role in the electronic publication at www.o-p-o.net of Essays in Celebration of the Foundation of the Organization of Phenomenological Organizations in 2003 and 2004. He has been one of strongest advocates and a major contributor to Zeta Books, a series that distributes its books both electronically and in print from Bucharest, Romania, with a distribution reach around the world.

Of course, in addition to Embree's very substantial contributions to the publication of work in phenomenology as a whole through his editions and establishment of new venues for publications in that area, one should not overlook the important contributions to phenomenology that Embree's own scholarly work represents. Most prominently to be named here is his Reflective Analysis that describes Embree's considered approach to phenomenological work in philosophy, other disciplines, and in daily life. This work, intended for both beginners and experts was translated into Castilian, Japanese, Russian, Polish, Romanian, and Chinese, and a number of other languages. His published production includes four other monographs and the impressive number of over 170 articles and book chapters in addition to numerous editions, bibliographies, and translations. Much of Embree's editorial work arose from another major form of his practical contributions to phenomenology, namely the numerous conferences on phenomenology that he has organized since he began his professional activities in this area with the symposium in honor of his teacher Aron Gurwitch in 1973 and published those essays as issue number 5 in the journal Research in Phenomenology.

Embree became one of the Husserl Circle's earliest members at its second meeting in 1969 and has remained one of its most active participants ever since, 
including hosting meetings at crucial points in the history of that organization in 1977 and 1994. He was an active member of the Merleau-Ponty Circle since its founding in 1974 and coordinated that group's meeting in 1977, and he was one of the founders and has served many years on the Executive Committee of the Society for Phenomenology and the Human Sciences (SPHS) that normally meets each year in conjunction with the Society for Phenomenology and Existential Philosophy (SPEP). One of Embree's positive contributions to SPEP, which he also attended regularly for fifty years, included the establishment of CARP's annual Aron Gurwitsch Memorial lecture at SPEP that has featured many of the most notable scholars in phenomenology from around the world and is often one of the best-attended events at the annual conference.

Embree's energy, organizational experience, and extensive personal contacts became especially apparent after his appointment to the William F. Dietrich Eminent Scholar in Philosophy Chair at Florida Atlantic University in 1990. Combining the resources of his endowed chair with his leadership in CARP, along with some funds generously bequeathed to CARP by Ilse Schutz and Alice Gurwitsch, the Seagate Inn in Delray Beach became a gathering place at conferences for leading phenomenologists from North America and around the world. Many of these are documented in the collections of essay in the Contributions to Phenomenology series mentioned above. They began with a conference he co-organized with John Drummond on "The Phenomenology of the Noema", followed by conferences on phenomenology and the natural sciences, phenomenology and the formal sciences, and phenomenology and the cultural disciplines, each time with a conference co-organizer who also took the lead in publishing the papers delivered at the conference. Other topics have included issue in Husserl's Ideas II, phenomenology and politics, phenomenological ethics, feminist phenomenology, Simone de Beauvoir's existential phenomenology, Merleau-Ponty's reading of Husserl, and Schutzian social science-to name just a few.

The other increasingly dominant focus of Embree's organizational energies during this time was facilitating contacts between members of the various phenomenological traditions around the world that for several decades had taken on a life of their own within their own nations or parts of the world and not been as actively in contact with each other as the North America and Western European phenomenologists have been since the end of World War II. One of the first 
conferences organized by CARP after Embree became president was a meeting organized by J.N. Mohanty and D.P. Chattopadhyaya with colleagues from the United States and India that was held in India in 1988. At his Delray Beach meetings, Embree had always included colleagues from Europe and Asia, but his impetus towards increasing international contacts across different national phenomenological traditions took a decisive turn as he was soliciting contributions to the comprehensive Encyclopedia of Phenomenology that was published in the CTP series in 1997. In addition to entries on topics and prominent figures in the phenomenological tradition, it included essays on the history of and current state of activity in phenomenology in a whole range of countries that included Australia, Austria, Canada, China, Czechoslovakia, France, Germany, Great Britain, Hungary, India, Italy, Japan, Korea, the Netherlands and Flanders, Poland, Portugal, Russia, Scandinavia, South Africa, Spain and Latin America, the United States, and Yugoslavia. In particular, this project identified phenomenological traditions in Korea, Japan, and China as well as in Latin America and Eastern Europe that were largely unknown to most scholars in North America and Western Europe at the time. He came to the conclusion that: "Given its spread into other disciplines as well as across the planet, phenomenology is arguably the major philosophical movement of the 20th century"6.

In commissioning these articles, Embree and his co-editors became personally acquainted with many of the leading practitioners of phenomenology in these parts of the world and in the years that followed the publication of the Encyclopedia, Embree consciously sought to find ways to support and foster these traditions and to bring together these scholars from around the world who previously had not known each other and their work. Under the CARP umbrella, Embree facilitated meetings between leading phenomenologists from North America and Western Europe and phenomenologists from Korea, Hong Kong, Japan, and Latin America, among others. In some of these cases, CARP was instrumental in the foundation of phenomenological organizations in these countries as well as in the Nordic countries of Europe, in Eastern Europe-in particular in Romania-and then just recently in the Mediterranean region. These include the Círculo LatinoAmericano de Fenomenología (CLAFEN), the Nordic Society of Phenomenology (NoSP), the Central and European Conference on Phenomenology (CEECOP), Phenomenology for East Asia CirclE (PEACE), and

\footnotetext{
${ }^{6}$ Lester Embree et al. (eds.), Encyclopedia of Phenomenology, p. 1.
} 
Reseau Euro-Mediterranean de Phénoménologie pour le Dialogue Intercultural (REM). These efforts culminated in the founding of the Organization of Phenomenological Organizations (OPO) under Embree's leadership in Prague in 2002 that brought together over 50 representatives of phenomenological organizations from around the world to present their work and find out about contemporary work in phenomenology from their intellectual compatriots in other parts of the world. Since then, OPO II met in Lima in 2003; OPO III in Hong Kong in December of 2008; OPO VI in Segovia Spain; OPO V in Perth, Australia in 2014; and OPO IV will meet in Memphis at the beginning of 2019. Ongoing communication between the members of these philosophical organizations and other interested scholars has been greatly facilitated by the "Newsletter of Phenomenology", which Embree was instrumental in establishing in 2002. This electronic newsletter provides information about recent publications in phenomenology in a whole range of languages, calls for papers and reports on conferences, news about recent appointments and other items on a monthly basis to over 3,750 subscribers. Lester Embree would be the first to emphasize the degree to which scholarly endeavors in general, and his own endeavors within phenomenology in particular have been a collaborative effort. His involvement in scholarly organizations, his editorial work, his role in establishing new venues for publication and organizing national and international conference in phenomenology have always been collaborative enterprises, involving teams of scholars and scholarly publishing houses. Embree has respected and acknow-ledge the legacies of those who went before in the phenomenological tradition; involved those currently contributing as scholars, co-editors, fellow organizers of conferences, and colleagues; and attempted whenever possible to involve younger scholars and future phenomenologists to become part of the enterprise of keeping phenomenology alive not just as a science, but as a living tradition. Lester Embree would admit that all his efforts have been part of a collaborative effort, but one can truly say that he has played a leading role in keeping phenomenology healthy as a scholarly and scientific approach to understanding and solving traditional philosophical problems as well as the global challenges facing us all in what is now the second century of the pheno-menological tradition as a global enterprise. 